\title{
Single Subject Research: Alternatif Penelitian Pendidikan Matematika di Masa New Normal
}

\author{
Sri Adi Widodo ${ }^{1 *}$, K Kustantini ${ }^{2}$, Krida Singgih Kuncoro ${ }^{1}$, Fiki Alghadari ${ }^{3}$ \\ ${ }^{1}$ Pendidikan Matematika, Universitas Sarjanawiyata Tamansiswa, Yogyakarta, Indonesia \\ ${ }^{2}$ Sekolah Luar Biasa A Yaketunis, Yogyakarta, Indonesia \\ ${ }^{3}$ Pendidikan Matematika, STKIP Kusuma Negara, Jakarta, Indonesia \\ *sriadi@ustjogja.ac.id
}

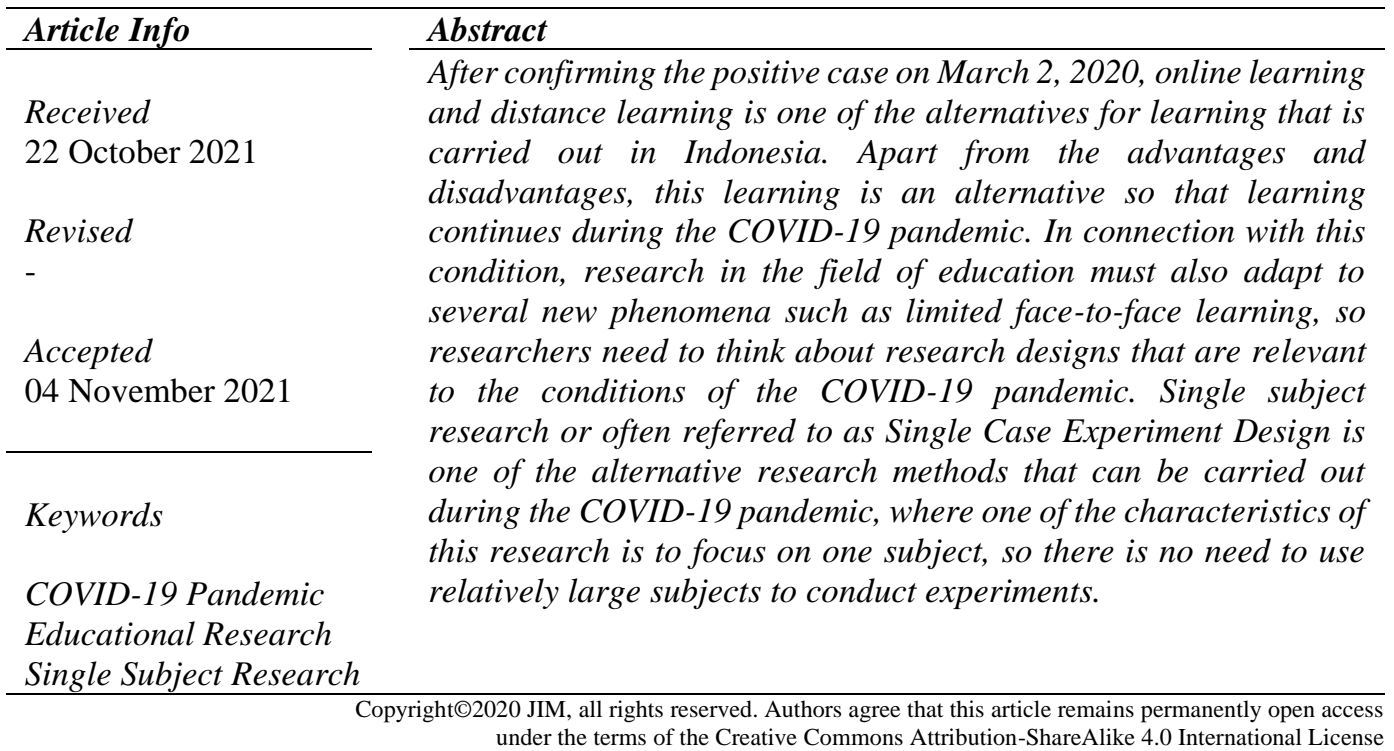

How to Cite:

Widodo, S. A., Kustantini, K., Kuncoro, K. S., \& Alghadari, F. (2021). Single Subject Research: Alternatif Penelitian Pendidikan Matematika di Masa New Normal. Journal of Instructional Mathematics, 2(2), 78-89.

\section{PENDAHULUAN}

Indonesia mengkonfirmasi kasus pertama COVID-19 pada tanggal 2 Maret 2020 (Setiawan, 2020; Setiawan \& Ilmiyah, 2020; Tosepu et al., 2020). Beberapa wilayah menerapkan karantina wilayah atau sering disebut dengan Pembatasan Sosial Berskala Besar (PSBB) seperti yang dilakukan di Provinsi DKI Jakara dan Kota Tegal. Bahkan hingga saat ini, bentuk karantina wilayah menjadi PPKM (Pemberlakuan Pembatasan Kegiatan Masyarakat). Walaupun kondisi kasus positif COVID-19 menunjukkan tren penurunan, diharapkan masyarakat tidak lengah dan terbawa euforia. Karena berdasarkan hasil pengamatan yang dilakukan oleh Dicky Budiman pakar epidemologi dari Universitas Grifftith, Australia bahwa Indonesia diprediksi memasuki gelombang ketiga COVID-19 apabila masyarakat Indonesia belum mempunyai imunitas untuk melawan virus atau tingkat vaksinasi yang masih cukup rendah (Amani, 2021). Bahkan Presiden Jokowi sendiri menyatakan bahwa COVID-19 tidak akan mungkin hilang secara total, sehingga cara terbaik untuk melindungi diri dari virus tersebut adalah dengan mengikuti vaksinasi dan menjalankan protokol kesehatan (CNN Indonesia, 2021; Kompas, 2021). 
Selain itu, pandemi COVID-19 juga merubah tatanan termasuk di bidang pendidikan yang selama ini bisa dikatakan sudah mapan. Sekolah dan universitas kemudian menerapkan model sekolah dari rumah (School From Home/SFH), dan tenaga pendidik dengan pola bekerja dari rumah (Work From Home/WFH). Baik SFH maupun WFH, sebagian besar tenaga pendidik melakukan pembelajaran online. Pendidik melalui platform sistem manajemen pembelajaran (Learning Management System) dikombinasi dengan konferensi video yang membantu peserta didik dalam kegiatan belajar (Gunawan et al., 2020; Sulisworo et al., 2020). Pembelajaran online di masa pandemi merupakan satu alternatif untuk tetap melaksanakan kegiatan belajar (Basilaia \& Kvavadze, 2020; Bauerlein, 2008; Laprairie \& Hinson, 2006; Taha et al., 2020). Hal ini dikarenakan pembelajaran online dapat digunakan di mana saja dan kapan saja (Bourne et al., 2005; Means, 2010; Nakamura et al., 2018; Özyurt et al., 2013). Namun, pembelajaran online atau e-learning menimbulkan banyak kendala seperti akses internet yang tidak merata di setiap daerah (Hung \& Chou, 2015; Smart \& Cappel, 2006; Van Bruggen, 2005). Oleh karena itu, pendidik yang belum memiliki pengalaman e-learning atau kurang sumber daya e-learning, mereka mengalami kesulitan mengimplementasikan, khususnya mereka yang belum memiliki kapasitas memadai tentang bagaimana menggunakan aplikasi online (Kim \& Bonk, 2006; Zaharah \& Kirilova, 2020).

Selama pemberlakuan PPKM level 1-3, pembelajaran tatap muka bisa dilakukan secara terbatas dengan kapasitas maksimal 50\% dan tetap mematuhi protokol kesehatan seperti yang tertuang dalam Instruksi Menteri Dalam Negeri Nomor $35 / 2021$. Menyingkapi kondisi ini, perlu adanya adaptasi metode penelitian selama masa pandemi. Peneliti perlu merencanakan penelitian yang harus dilakukan dan protokol kesehatan wajib menjadi bahan pertimbangan tatkala memilih metode penelitian yang tepat. Artinya, metode yang tepat tidak saja mesti mencerminkan kebutuhan, model dan pertanyaan yang ingin dijawab dari sebuah penelitian, tetapi juga mematuhi standar protokol kesehatan. Sebagai contoh penelitian kuantitatif dengan desain eksperimen pretest-posttest control group design yang selama ini dilakukan dengan subyek penelitian besar tidak dapat dilaksanakan di masa normal baru karena terkendala dengan Instruksi Menteri Dalam Negeri tersebut. Hal ini tentu menjadi tantangan tersendiri khususnya bagi penelitian yang ada dalam rumpun pendidikan matematika. Dengan kata lain, metode penelitian yang selama ini dilakukan sebelum pandemi, harus diadaptasi dengan kondisi pandemi COVID19. Proses adaptasi tersebut karena peneliti tidak selalu dapat menghadirkan siswa dalam jumlah besar untuk diberikan treatment atau perlakuan secara tatap muka.

\section{METODE PENELITIAN}

Penelitian ini merupakan penelitian studi pustaka dan tidak dimaksudkan untuk membuat produk penelitian atau menguji keefektifan suatu intervensi atau treatment. Berkaitan dengan hal ini maka peneliti menggunakan sumber yang berasal dari jurnal dan buku yang berkaitan dengan single subject research, serta mengaitkannya dengan penelitian di kondisi pandemi saat ini. 


\section{Single Subject Research}

\section{HASIL DAN PEMBAHASAN}

Penelitian subjek tunggal adalah penelitian yang banyak digunakan di bidang pendidikan luar biasa dengan karakteristik siswa berkebutuhan khusus (Cakiroglu, 2012; Widodo et al., 2021). Tetapi tidak mustahil metode penelitian ini dapat dilakukan untuk subyek dengan kondisi subjek normal atau tidak berkebutuhan khusus (Widodo et al., 2020; Yanti et al., 2018). Penelitian subjek tunggal adalah jenis penelitian kuantitatif yang mempelajari secara rinci perilaku masing-masing dari sejumlah kecil subjek (Gast \& Ledford, 2014). Single subject research merupakan penelitian eksperimen untuk melihat perilaku dan mengevaluasi intervensi atau treatment tertentu atas perilaku dari suatu subyek tunggal dengan penilaian yang dilakukan secara berulang-ulang dalam suatu waktu tertentu (Prahmana, 2021). Karena penelitian subjek tunggal merupakan penelitian kuantitatif dengan memberikan intervensi atau treatment kepada subyek penelitian dalam jangka waktu tertentu, banyak ahli menyatakan bahwa single subject research merupakan single case experiment design atau SCED (Kazdin, 2021; Lane \& Gast, 2014; Rassafiani \& Sahaf, 2010; Smith, 2012). Istilah subjek tunggal tidak berarti bahwa hanya satu subyek penelitian yang dipelajari, tetapi itu lebih khas untuk berada di suatu tempat antara satu hingga lima peserta (Gast \& Ledford, 2014; Lane \& Gast, 2014). Hal inilah yang menyebabkan bahwa desain penelitian subjek tunggal kadang-kadang disebut desain kecil- $n$, di mana $n$ adalah simbol statistik untuk ukuran sampel.

Beberapa karakteristik penelitian subjek tunggal diantaranya adalah sebagai berikut. Pertama, fokus pada perilaku subyek penelitian (Busk \& Marascuilo, 2015; Kratochwill, 2013). Salah satu alasannya adalah bahwa penelitian kelompok dapat menyembunyikan perbedaan individu dan menghasilkan hasil yang tidak mewakili perilaku individu mana pun. Misalnya, pengaruh model pembelajaran A yang memiliki efek positif bagi sebagian siswa, tetapi efek negatif bagi sebagian lainnya, secara rata-rata dapat dimungkinkan pembelajaran A tidak berpengaruh sama sekali. Penelitian subjek tunggal, kemungkinan untuk mengungkapkan perbedaan individu ini sangat dimungkinkan. Alasan lainnya adalah untuk memusatkan perhatian secara intensif kepada individu yang terkadang perilaku individu tersebut menarik untuk diungkapkan.

Kedua, untuk menemukan hubungan sebab akibat melalui manipulasi variabel independen, pengukuran yang cermat terhadap variabel dependen, dan pengendalian variabel asing (Datiilo et al., 2000; Horner et al., 2005; Koscinski \& Gast, 1993; Stringfield et al., 2011). Untuk alasan ini, penelitian subjek tunggal sering dianggap sebagai jenis penelitian eksperimental dengan validitas internal yang baik. Misalnya, siswa dengan kategori introvert diukur prestasi belajarnya secara berkali-kali. Pertama di bawah kondisi kontrol tanpa perlakuan, kemudian di bawah kondisi perlakuan dengan menggunakan media pembelajaran, dan selanjutnya lagi di bawah kondisi kontrol. Karena ada peningkatan yang jelas dalam belajar saat diberikan perlakuan dengan menggunakan media pembelajaran, penurunan saat dihilangkan media pembelajaran, dan peningkatan saat menggunakan media pembelajaran kembali, tidak ada sedikit keraguan untuk menyimpulkan bahwa media pembelajaran yang digunakan merupakan penyebab perbaikan prestasi belajar siswa introvert. 
Ketiga, penelitian subjek tunggal bertujuan mempelajari efek yang kuat dan konsisten yang memiliki kepentingan biologis atau sosial. Peneliti terapan, biasanya tertarik pada treatment yang memiliki efek substansial pada perilaku dan dapat diimplementasikan dengan andal dalam konteks dunia nyata di mana mereka terjadi. Ini kadang-kadang disebut sebagai validitas sosial (Horner et al., 2005; Wolf, 1978). Hal ini sejalan dengan pernyataan yang disampaikan oleh Prahmana (2021) bahwa tujuan single subject research adalah untuk menjelaskan dengan jelas efek dari suatu intervensi yang diberikan secara berulang ulang dalam waktu tertentu agar perubahan perilaku atau respon individu dapat dipastikan berasal dari intervensi yang diberikan bukan dari faktor lain.

Selain itu, karakteristik lainnya desain penelitian tunggal memerlukan penilaian berkelanjutan atau berkelanjutan dari waktu ke waktu, sehingga treatment diberikan pada beberapa kesempatan dalam fase terpisah. Selanjutnya bahwa, efek intervensi biasanya direplikasi dalam peserta yang sama dari waktu ke waktu, sehingga setiap fase dapat mengambil keuntungan dari penilaian berulang dari waktu ke waktu dan evaluasi kinerja dalam kondisi yang berbeda (Horner et al., 2005; Kazdin, 2021).

\section{Desain Penelitian Penelitian Tunggal}

Sebelum melihat desain penelitian subjek tunggal, akan sangat membantu untuk mempertimbangkan beberapa hal yang umum bagi para peneliti single subject research. Pertama, variabel dependen (diwakili pada sumbu $y$ dari grafik) diukur berulang kali dari waktu ke waktu (diwakili oleh sumbu $x$ ) secara berkala (lihat Gambar 1). Kedua, penelitian dibagi menjadi beberapa fase yang berbeda, dan peserta diuji dalam satu kondisi per fase. Kondisi sering ditandai dengan huruf kapital: A, B, C, dan seterusnya. Pada Gambar 1, fase A disebut dengan fase baseline dan B disebut dengan fase intervensi. Apabila melihat Gambar 3, maka fase $\mathrm{A}$ adalah fase baseline, fase $\mathrm{B}$ adalah fase intervensi 1, dan fase $\mathrm{C}$ adalah intervensi 2.

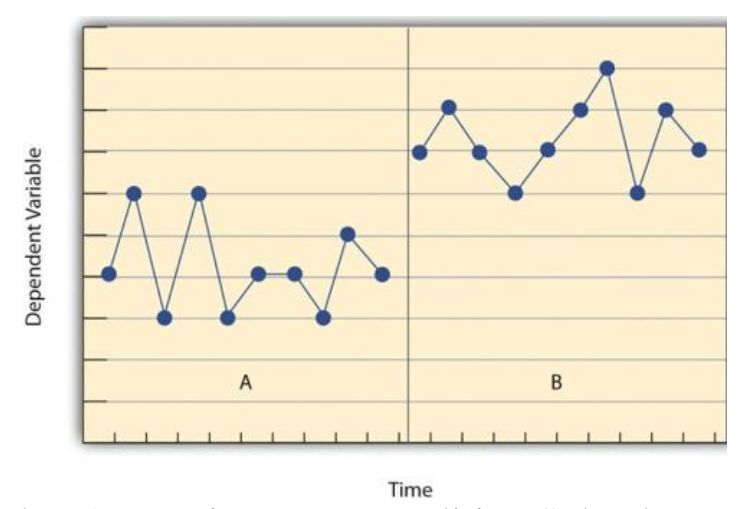

Gambar 1. Desain Dasar Penelitian Subyek Tunggal

Gambar 1 merupakan desain dasar penelitian subjek tunggal tanpa pembalikan, juga disebut desain $\mathrm{AB}$ karena pengumpulan data dari subyek penelitian hanya melibatkan dua fase yaitu fase baseline dan fase intervensi (Prahmana, 2021; Sunanto et al., 2005). Aspek penting dari penelitian subjek tunggal adalah perubahan dari satu kondisi ke kondisi berikutnya biasanya tidak terjadi setelah sejumlah waktu atau jumlah pengamatan yang tetap. Secara khusus, peneliti menunggu sampai perilaku partisipan dalam satu kondisi menjadi cukup konsisten 
dari observasi ke observasi sebelum mengubah kondisi. Idenya adalah bahwa ketika variabel dependen telah mencapai kondisi mapan, maka setiap perubahan di seluruh kondisi akan relatif mudah dideteksi.

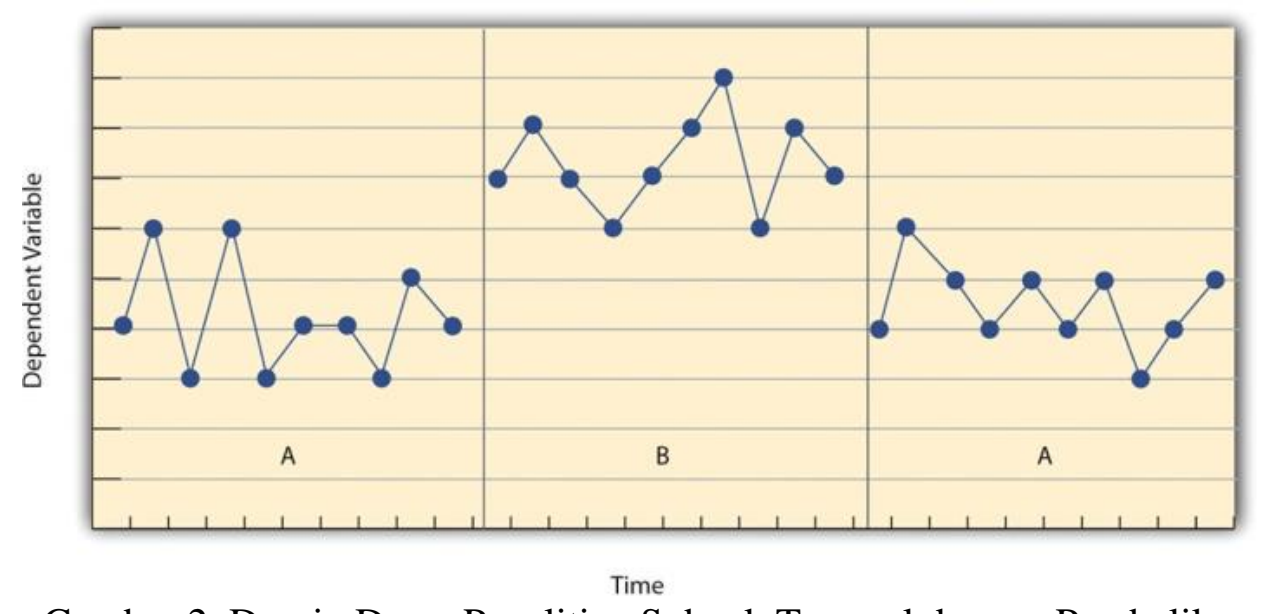

Gambar 2. Desain Dasar Penelitian Subyek Tunggal dengan Pembalikan

Gambar 2 merupakan desain penelitian subjek tunggal dengan pembalikan, juga disebut desain ABA (Datiilo et al., 2000; Gast \& Ledford, 2014; Koscinski \& Gast, 1993; Lane \& Gast, 2014). Selama fase pertama, sebuah baseline ditetapkan untuk variabel dependen. Ini adalah tingkat respon sebelum subjek diberikan perlakuan apapun, dan oleh karena itu fase ini dapat disebut dengan kondisi kontrol. Ketika respons kondisi mapan tercapai, fase B dapat dilakukan dengan memberikan treatment atau intervensi kepada subyek peneliti. Mungkin ada periode penyesuaian terhadap perlakuan di mana perilaku minat menjadi lebih bervariasi dan mulai meningkat atau menurun. Sekali lagi, peneliti harus menunggu sampai variabel dependen tersebut mencapai kondisi mapan sehingga jelas apakah dan seberapa banyak ia telah berubah. Akhirnya, peneliti menghapus perlakuan dan menunggu lagi sampai variabel dependen mencapai kondisi mapan. Desain pembalikan dasar ini juga dapat diperpanjang dengan pengenalan kembali treatment (ABAB), pengembalian lain ke baseline (ABABA), dan seterusnya.

Pembalikan (reversal atau withdrawl) sangat diperlukan dalam jenis desain ini. Hal ini bertujuan untuk meyakinkan peneliti bahwa intervensi (treatment) yang diberikan kepada subyek benar benar memberikan efek kepada subyek dan tidak dipengaruhi oleh faktor lain (Datiilo et al., 2000; Koscinski \& Gast, 1993; Stringfield et al., 2011). Pada desain AB pada dasarnya adalah desain deret waktu terputus yang diterapkan pada peserta individu. Satu masalah dengan desain AB adalah jika variabel dependen berubah setelah perlakuan diperkenalkan, tidak terlalu jelas apakah perlakuan itu bertanggung jawab atas perubahan tersebut atau tidak. Ada kemungkinan bahwa sesuatu yang lain berubah pada waktu yang hampir bersamaan dan bahwa variabel asing ini bertanggung jawab atas perubahan variabel terikat. Tetapi jika variabel dependen berubah dengan pengenalan treatment dan kemudian berubah kembali dengan penghapusan treatment (dengan asumsi bahwa treatment tidak menimbulkan efek permanen), jauh lebih jelas bahwa treatment (dan penghapusan treatment) adalah penyebab.

Desain lain dari pembalikan dasar yang memungkinkan evaluasi lebih dari satu perlakuan, yaitu multiple treatmen reversal design. Misalnya, seorang peneliti 
mungkin menetapkan dasar perilaku belajar untuk siswa (A), kemudian memperkenalkan perlakuan yang melibatkan perhatian positif dari guru (B), dan kemudian beralih ke perlakuan yang melibatkan hukuman ringan karena tidak belajar (C). Subjek kemudian dapat dikembalikan ke fase awal sebelum memperkenalkan kembali setiap perlakuan, dimungkin dalam urutan terbalik sebagai cara untuk mengendalikan efek sisa. Multiple treatmen reversal juga dapat disebut sebagai desain ABCACB (Gambar 3).

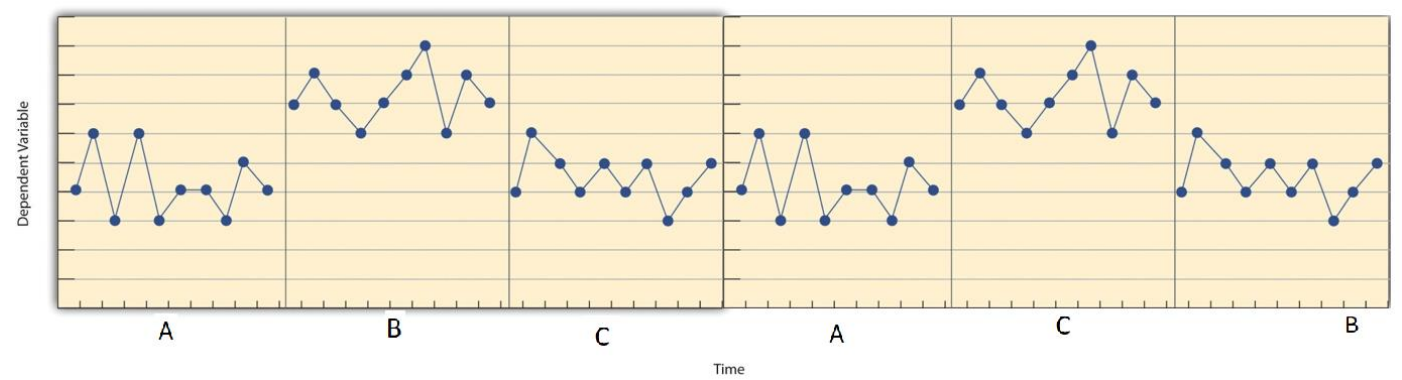

Gambar 3. Penelitian Subyek Tunggal dengan desain ABCACB

\section{Teknik Analisis Data pada Single Subject Research}

Selain fokusnya pada subjek penelitian, penelitian ini berbeda dari penelitian kelompok yang biasanya dilakukan di bidang pendidikan. Analisis data pada penelitian kelompok seperti pada penelitian eksperimen, melibatkan penggabungan data antar subjek penelitian, selanjutnya dideskripsikan menggunakan statistik seperti mean, standar deviasi, atau variansi, akhirnya menggunakan statistik inferensial untuk membantu memutuskan apakah hipotesis yang diajukan diterima atau tidak. Sebaliknya penelitian subjek tunggal, sangat bergantung pada pendekatan yang sangat berbeda yang disebut inspeksi visual. Ini berarti memplot data subjek penelitian pada sebuah grafik, dilihat dengan cermat data tersebut, dan membuat penilaian sejauh mana variabel independen berpengaruh pada variabel dependen.

Dalam memeriksa data pada penelitian single subject research dapat menggunakan analisis secara visual atau visual inspection (Bobrovitz \& Ottenbacher, 1998; Kratochwill, 2013; Ottenbacher, 1990). Walaupun teknik analisis ini masih diperdebatkan (Kromrey \& Foster-johnson, 1996), tetapi teknik analisis data ini pernah dilakukan oleh beberapa peneliti seperti Bobrovitz \& Ottenbacher (1998), Ottenbacher (1990), dan Park et al (1990). Pada teknik analisis ini, peneliti perlu mempertimbangkan beberapa faktor, salah satunya adalah perubahan tingkat variabel dependen dari kondisi ke kondisi. Jika variabel dependen jauh lebih tinggi atau jauh lebih rendah dalam satu kondisi dari pada yang lain, ini menunjukkan bahwa treatment memiliki efek. Faktor kedua adalah tren, yang mengacu pada peningkatan atau penurunan bertahap dalam variabel dependen di seluruh pengamatan. Jika variabel dependen mulai meningkat atau menurun dengan perubahan kondisi, sekali lagi ini menunjukkan bahwa treatment memiliki efek. Ini dapat secara khusus memberi tahu ketika tren berubah arah, seperti ketika perilaku yang tidak diinginkan meningkat selama baseline tetapi kemudian mulai menurun dengan diperkenalkannya treatment. Faktor ketiga adalah latency, yang merupakan waktu yang dibutuhkan variabel dependen untuk mulai berubah setelah perubahan kondisi. 

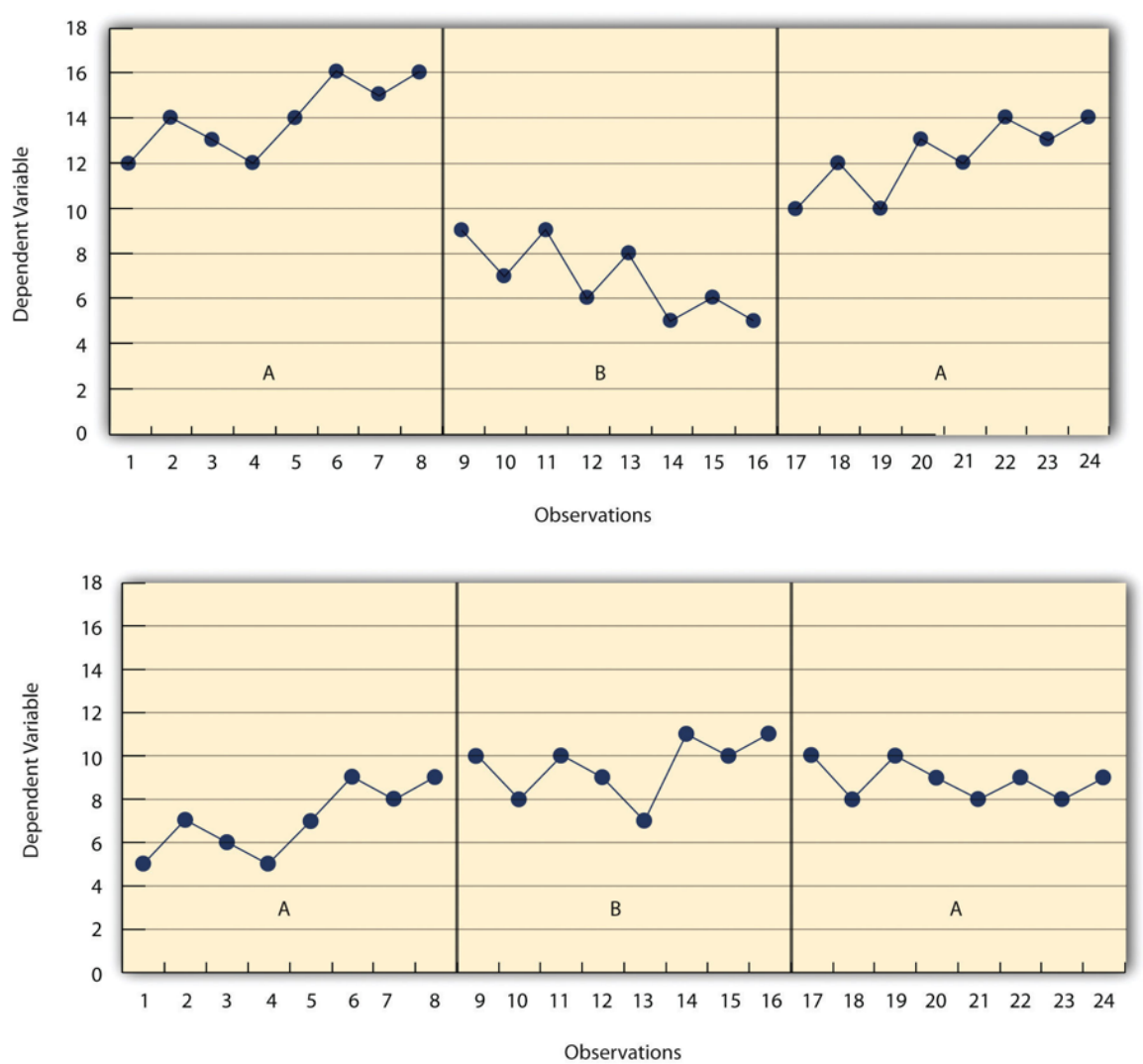

Gambar 4. Perubahan Level Single Subject Research Secara Visual

Pada Gambar 4, terdapat perubahan yang cukup jelas pada level dan tren variabel dependen dari kondisi ke kondisi. Selain itu, latency dari perubahan ini pendek; perubahan segera terjadi. Pola hasil ini sangat menunjukkan bahwa treatment bertanggung jawab atas perubahan variabel dependen. Namun, Gambar 4 bawah, perubahan level cukup kecil, meskipun tampaknya ada tren yang meningkat dalam kondisi treatment, tampaknya ini mungkin merupakan kelanjutan dari tren yang telah dimulai selama baseline. Pola hasil ini dengan kuat menunjukkan bahwa treatment tidak bertanggung jawab atas perubahan apa pun pada variabel dependen.

Hasil penelitian subjek tunggal juga dapat dianalisis menggunakan prosedur statistic inferensial seperti uji-t atau analisis varians (Fisch, 2001; Neuman \& McCormick, 1995). Rata-rata dan standar deviasi dari baseline setiap peserta dihitung dan dibandingkan, dan uji statistik inferensial seperti uji- $t$ atau analisis varians diterapkan (Fisch, 2001). Tetapi teknik analisis data ini masih menjadi perdebatan (Busk \& Marascuilo, 2015), seperti penggunaan ukuran sampel sebesar 1 atau kurang dari 5, termasuk teknik pengambilan sampel yang tidak random sehingga asumsi klasikal statistika inferensial tidak terpenuhi.

Pendekatan lain yang dapat digunakan untuk melakukan analisis data penelitian subjek tunggal dapat menggunakan persentase data yang tidak tumpang tindih (percentage of nonoverlapping data/PND) untuk setiap subjek penelitian (Manolov \& Solanas, 2009; Parker et al., 2007; Scruggs \& Mastropieri, 1998, 2001). Pada teknik analisis data ini dilakukan dengan cara (1) menentukan nilai baseline maksimum pada grafik, (2) menarik garis horizontal dari nilai maksimum yang 
ditentukan ini ke kanan (tingkat intervensi), (3) menentukan nilai tingkat intervensi di atas garis horizontal ini, (4) membagi jumlah titik data yang diperoleh pada langkah ketiga dengan jumlah total titik data pada tingkat intervensi, dan (5) nilai yang diperoleh pada langkah keempat dikalikan dengan 100 untuk menghitung nilai PND (Sşen \& Sşen, 2019). Asumsi yang digunakan pada teknik analisi data ini adalah jika PND $>90 \%$ maka intervensi yang diberikan kepada subjek sangat efektif, jika diperoleh PND antara $71 \%$ hingga $90 \%$ maka intervensi dapat dinyatakan efektif, jika diperoleh PND antara 50\% hingga 70\% maka intervensi kategori sedang, jika PND kurang dari 50\% maka tidak efektif (Scruggs et al., 1986; Strain et al., 1992).

Teknik analisis data yang sangat familiar dilakukan oleh peneliti dalam melakukan penelitian subyek tunggal dapat menggunakan metode split half atau metode belah dua (Prahmana, 2021; Sunanto et al., 2005). Pada metode split half, dilakukan dua analisis yaitu analisis dalam kondisi dan analisis antar kondisi. Analisis dalam kondisi adalah analisis yang dilakukan pada kondisi baseline dan kondisi intervensi (James, 2016; Prahmana, 2021; Sunanto et al., 2005). Komponen yang digunakan untuk melakukan analisis pada kondisi ini adalah: (1) menentukan panjang kondisi, (2) menentukan estimasi kecenderungan arah, (3) menentukan tren kestabilan, (4) menentukan tren jejak data, (5) menentukan level stabilitas dan rentang, dan (6) menentukan level perubahan. Analisis antar kondisi dilakukan untuk melihat perbedaan antara fase baseline dan fase intervensi (Freeman \& Eagle, 2011; Gast \& Ledford, 2014). Sedangkan komponen yang digunakan untuk melakukan analisis kondisi ini meliputi: (1) menentukan jumlah variabel yang diubah, (2) menentukan perubahan kecenderungan arah, (3) menentukan perubahan tren stabilitas, (4) menentukan level perubahan, dan (5) menentukan overlap dari kondisi baseline dan intervensi.

\section{KESIMPULAN}

COVID-19 tidak mungkin hilang dalam waktu dekat, untuk itu penelitian harus beradaptasi dengan kondisi tersebut agar penelitian tetap berjalan. Berdasarkan pembahasan tersebut, single subject research atau penelitian dengan subyek tunggal dapat dijadikan alternatif metode penelitian di era new normal. Hal ini dikarenakan salah satu karakteristik metode penelitian ini diantaranya adalah hanya membutuhkan subyek dalam jumlah yang relatif kecil, sehingga tidak perlu menghadirkan subyek yang besar untuk diberikan perlakuan atau treatment.

\section{REFERENSI}

Amani, M. (2021). Gelombang Ketiga COVID-19 RI Diprediksi Desember, Ini Peringatan Epidemiolog. Kompas.Com, 2021.

Basilaia, G., \& Kvavadze, D. (2020). Transition to Online Education in Schools during a SARS-CoV-2 Coronavirus (COVID-19) Pandemic in Georgia. Pedagogical Research, 5(4), 1-9. https://doi.org/10.29333/pr/7937

Bauerlein, M. (2008). Online literacy is a lesser kind: Slow reading counterbalances Web skimming. The Chronicle of Higher Education, 54(31).

Bobrovitz, C. D., \& Ottenbacher, K. J. (1998). Comparison of visual inspection and statistical analysis of single-subject data in rehabilitation research. American 
Journal of Physical Medicine \& Rehabilitation, 77(2), 94-102. https://doi.org/10.1097/00002060-199803000-00002

Bourne, J., Harris, D., \& Mayadas, F. (2005). Online Engineering Education: Learning Anywhere, Anytime. Journal of Engineering Education, 94(1), 131146. https://doi.org/10.1002/j.2168-9830.2005.tb00834.x

Busk, P. L., \& Marascuilo, L. A. (2015). Statistical analysis in single-case research: Issues, procedures, and recommendations, with applications to multiple behaviors. In Single-case research design and analysis (psychology revivals) (pp. 171-198). Routledge.

Cakiroglu, O. (2012). Single subject research: Applications to special education. British Journal of Special Education, 39(1), 21-29. https://doi.org/10.1111/j.1467-8578.2012.00530.x

CNN Indonesia. (2021). Jokowi : COVID-19 Tidak Mungkin Hilang Total J. CNN Indonesia.

Datiilo, J., Gast, D. L., Loy, D. P., \& Malley, S. (2000). Use of Single -Subject Research Designs in Therapeutic Recreation. Therapeutic Recreation Journal, . 34(3), 253-270.

Fisch, G. S. (2001). Evaluating data from behavioral analysis: Visual inspection or statistical models? Behavioural Processes, 54(1-3), 137-154. https://doi.org/10.1016/S0376-6357(01)00155-3

Freeman, K. A., \& Eagle, R. F. (2011). Single-subject research designs. In Understanding Research in Clinical and Counseling Psychology, Second Edition (pp. 124-154). https://doi.org/10.4324/9780203831700

Gast, D. L., \& Ledford, J. R. (2014). Single subject research methodology in behavioral sciences. Routledge.

Gunawan, G., Suranti, N. M. Y., \& Fathoroni, F. (2020). Variations of Models and Learning Platforms for Prospective Teachers During the COVID-19 Pandemic Period. Indonesian Journal of Teacher Education, 1(2), 61-70.

Horner, R. H., Carr, E. G., Halle, J., McGee, G., Odom, S., \& Wolery, M. (2005). The use of single-subject research to identify evidence-based practice in special education. Exceptional Children, 71(2), 165-179. https://doi.org/10.1177/001440290507100203

Hung, M. L., \& Chou, C. (2015). Students' perceptions of instructors' roles in blended and online learning environments: A comparative study. Computers and Education, 81, 315-325. https://doi.org/10.1016/j.compedu.2014.10.022

James, K. P. (2016). Single-subject research method: The needed simplification. British Journal of Education, 4(6), 68-95.

Kazdin, A. E. (2021). Single-case experimental designs: Characteristics, changes, and challenges. Journal of the Experimental Analysis of Behavior, 115(1), 5685. https://doi.org/10.1002/jeab.638

Kim, K.-J., \& Bonk, C. (2006). The future of online teaching and learning in higher education. Educause quarterly, 29(4), 22-30.

Kompas. (2021). Jokowi: COVID-19 Tak Mungkin Hilang Secara Total ... Kompas.Com.

Koscinski, S. T., \& Gast, D. L. (1993). Use of Constant Time Delay in Teaching Multiplication Fact to Students with LEarning Disabilities. Journal of Learning Disabilities, 26(8), 533-544. https://doi.org/10.1177/002221949302600807

Kratochwill, T. R. (2013). Single subject research: Strategies for evaluating 
change. Academic Press.

Kromrey, J. D., \& Foster-johnson, L. (1996). Determining the efficacy of intervention: The use of effect sizes for data analysis in single-subject research. Journal of Experimental Education, 65(1), 73-93. https://doi.org/10.1080/00220973.1996.9943464

Lane, J. D., \& Gast, D. L. (2014). Visual analysis in single case experimental design studies: Brief review and guidelines. Neuropsychological Rehabilitation, 24(34), 445-463. https://doi.org/10.1080/09602011.2013.815636

Laprairie, K. N., \& Hinson, J. M. (2006). When Disaster Strikes, Move Your School Online. Journal of Educational Technology Systems, 35(2), 209-214. https://doi.org/10.2190/d154-xk20-7264-5013

Manolov, R., \& Solanas, A. (2009). Percentage of nonoverlapping corrected data. Behavior Research Methods, 41(4), 1262-1271. https://doi.org/10.3758/BRM.41.4.1262

Means, B. (2010). Technology and education change: Focus on student learning. Journal of Research on Technology in Education, 42(3), 285-307. https://doi.org/10.1080/15391523.2010.10782552

Nakamura, Y., Yoshitomi, K., \& Kawazoe, M. (2018). Distance Learning, ELearning and Blended Learning in Mathematics Education. In Distance Learning, E-Learning and Blended Learning in Mathematics Education. https://doi.org/10.1007/978-3-319-90790-1

Neuman, S. B., \& McCormick, S. (1995). Single Subject Experimental Research: Application for Literacy. International Reading Association.

Ottenbacher, K. J. (1990). Visual inspection of single-subject data: An empirical analysis. Mental Retardation, 28(5), 283-290.

Özyurt, Ö., Özyurt, H., Baki, A., \& Güven, B. (2013). Integration into mathematics classrooms of an adaptive and intelligent individualized e-learning environment: Implementation and evaluation of UZWEBMAT. Computers in Human Behavior, 29(3), 726-738. https://doi.org/10.1016/j.chb.2012.11.013

Parker, R. I., Hagan-Burke, S., \& Vannest, K. (2007). Percentage of all nonoverlapping data (PAND) an alternative to PND. The Journal of Special Education, 40(4), 194-204. https://doi.org/10.1177/00224669070400040101

Prahmana, R. C. I. (2021). Single Subject Research (Teori dan Implementasinya: Suatu Pengantar). UAD Press.

Rassafiani, M., \& Sahaf, R. (2010). Single case experimental design: an overview. International Journal of Therapy and Rehabilitation, 17(6), 285-289. https://doi.org/10.12968/ijtr.2010.17.6.48151

Scruggs, T. E., \& Mastropieri, M. A. (1998). Summarizing single-subject research: Issues and applications. Behavior Modification, 22(3), 221-242. ttps://doi.org/10.1177/01454455980223001

Scruggs, T. E., \& Mastropieri, M. A. (2001). How to summarize single-participant research: Ideas and applications. Exceptionality, 9(4), 227-244.

Scruggs, T. E., Mastropieri, M. A., Cook, S. B., \& Escobar, C. (1986). Early Intervention for Children with Conduct Disorders: A Quantitative Synthesis of Single-Subject Research. Behavioral Disorders, 11(4), 260-271. https://doi.org/10.1177/019874298601100408

Setiawan, A. R. (2020). Scientific Literacy Worksheets for Distance Learning in the Topic of Coronavirus 2019. Reading Academic Article. 
https://doi.org/10.1016/j.solener.2019.02.027

Setiawan, A. R., \& Ilmiyah, S. (2020). Students' Worksheet for Distance Learning Based on Scientific Literacy in the Topic Coronavirus Disease 2019 (COVID19). EdArXiv. https://doi.org/DOI: https://doi.org/10.35542/osf.io/h4632

Smart, K. L., \& Cappel, J. L. (2006). Students' Perceptions of Online Learning: A Comparative Study. Journal of Information Technology Education: Research, 5(1), 201-219. https://doi.org/10.28945/243

Smith, J. D. (2012). Single-case experimental designs: a systematic review of published research and current standards. Psychological Methods, 17(4), 510. https://doi.org/10.1037/a0029312

Sşen, N., \& Sşen, S. (2019). Calculation of effect size in single-subject experimental studies: Examination of non-regression-based methods. Journal of Measurement and Evaluation in Education and Psychology, 10(1), 30-48. https://doi.org/10.21031/epod.419625

Strain, P. S., Kohler, F. W., \& Gresham, F. (1992). Problems in Logic and Interpretation with Quantitative Syntheses of Single-Case Research: Mathur and Colleagues (199S) as a Case in Poin. Behavioral Disorder, 24(I), 74-85. https://doi.org/10.1177/019874299802400107

Stringfield, S. G., Luscre, D., \& Gast, D. L. (2011). Effects of a story map on accelerated reader postreading test scores in students with high-functioning autism. Focus on Autism and Other Developmental Disabilities, 26(4), 218229. https://doi.org/10.1177/1088357611423543

Sulisworo, D., Rohmadheny, P. S., Fatimah, N., \& Arif, D. B. (2020). Learning analytics to predict student achievement in online learning during COVID- 19 mitigation. International Journal of Psychosocial Rehabilitation, 24(10), 18441861. https://doi.org/10.37200/IJPR/V24I10/PR300210

Sunanto, J., Takeuchi, K., \& Nakata, H. (2005). Pengantar Penelitian Dengan Subyek Tunggal. UPI Press.

Taha, M. H., Abdalla, M. E., Wadi, M., \& Khalafalla, H. (2020). Curriculum delivery in Medical Education during an emergency: A guide based on the responses to the COVID-19 pandemic. MedEdPublish, 9. https://doi.org/10.15694/mep.2020.000069.1

Tosepu, R., Gunawan, J., Effendy, D. S., Ahmad, L. O. A. I., Lestari, H., Bahar, H., \& Asfian, P. (2020). Correlation between weather and COVID-19 pandemic in Jakarta, Indonesia. Science of the Total Environment. https://doi.org/10.1016/j.scitotenv.2020.138436

Van Bruggen, J. (2005). Theory and practice of online learning. British Journal of Educational Technology, 36(1), 111-112. https://doi.org/10.1111/j.14678535.2005.00445_1.x

Widodo, S. A., Cahyani, E. R., \& Istiqomah, I. (2020). Single Subject Research : Learning Algebra Operations in Introverted Students. Formatif: Jurnal Ilmiah $\begin{array}{lll}\text { Pendidikan } & \text { 10(2), 133-142. }\end{array}$ http://dx.doi.org/10.30998/formatif.v10i2.6300

Widodo, S. A., Prihatiningsih, A., \& Taufiq, I. (2021). Single subject research: Use of interactive video in children with developmental disabilities with dyscalculia to introduce natural numbers. Participatory Educational Research. https://doi.org/10.17275/per.21.31.8.2

Wolf, M. M. (1978). Social validity: the case for subjective measurement or how 
applied behavior analysis is finding its heart 1. Journal of Applied Behavior Analysis, 11(2), 203-214. https://doi.org/10.1901/jaba.1978.11-203

Yanti, O. F., Prahmana, R. C. I., \& Fitriyah, F. (2018). Single Subject Research: Pembelajaran Phytagoras Pada Siswa Introvert Kelas VIII. Beta Jurnal Tadris Matematika, 11(1), 37-49. https://doi.org/10.20414/betajtm.v11i1.147

Zaharah, Z., \& Kirilova, G. I. (2020). Impact of Corona Virus Outbreak Towards Teaching and Learning Activities in Indonesia. SALAM: Jurnal Sosial Dan Budaya Syar-I, 7(3), 269-282. https://doi.org/10.15408/sjsbs.v7i3.15104 